\title{
Grouting design for slope stability of kedung uling earthfill dam
}

\author{
Najib $^{1, *}$, Agus Setyawan ${ }^{2}$, and Dwiyanto Joko Suprapto ${ }^{1}$ \\ ${ }^{1}$ Geological Engineering Department, Engineering Faculty, Diponegoro University, Indonesia \\ ${ }^{2}$ Physics Department, Mathematics and Science Faculty, Diponegoro University, Indonesia
}

\begin{abstract}
Kedung Uling earthfill dam locates at Wonogiri Regency, Central Java, Indonesia. The dam encountered sliding and settlement at the embankment wall. To minimize sliding and settlement and to optimize the dam, both field investigation and laboratory tests have been proceeded for slope stability analysis and remedial embankment wall. Soil and rock investigation around the dam, which is followed by 10 core drillings, have been conducted. Laboratory tests such as direct shear and index properties have also been carried on. The results were further used for dam slope stability model using slide 6.0 and were used to analyzed factor of safety (FS) of Kedunguling dam. 10 conditions of dam were simulated and strengthening body of dam with grouting was designed. The results showed two conditions, which are condition of maximum water level with and without earthquake at downstream, were unsatisfy Indonesia National Standard (SNI) for building and infrastructure. These conditions can be managed by using grouting for increasing stabilization of embankment wall. By setting up grouting, factor of safety increases and meet the SNI standard requirement.
\end{abstract}

\section{Introduction}

Kedung Uling earthfill dam is one of many old earthfill dams in Indonesia. The dam which was established on 1917, locates at Wonogiri Regency, Central Java, Indonesia. The dam lies on between Jatirejo and Tempuran river. Kedung Uling dam which has main function for irigation has $479.000 \mathrm{~m}^{3}$ capacity and distributing irigation for 596 hectare rice fields. Other functions of this dam are for tourism and fishery fresh water. In 2013 to 2014, the dam was encountered sliding and settlement at the embankment wall. These such problems affect function of dam such as releasing water in big quantity, disturbance risk people or infrastructures at the downstream [1].Therefore, It is strongly required to analyze the slope stability of Kedung Uling dam for overcoming the problems. Besides, water capacity of the dam can be increased by optimizing the dam for fulfilling water needs.

Dam Optimazing can be done by increasing height of top of the dam. This solution can be done by adding filling material at the body of dam. However, increasing the top of dam with impervious filling materials without good engineering solution cause the problems such as sliding, settlement or piping as happened in Kedunguling dam.

One of solutions for strenghtening filling soil in earthfill dam is by using grouting method $[2,3]$. Grouting has more benefit than another method such as grouting can be installed in the finite area, more efective and no need formidable tools and does not change slope geometry. Curtain grouting has already implemented in overcoming dam seepage with the bedrock of dam is limestone, eventhough piping still continue due to its porous litology [4]. Therefore, it needs to calculate the effective of composition for implementing of curtain grouting especially for dam foundation rehabilitation [5]. It is expected that by appropriate composition, grouting will increase value of cohesion and decreasing internal friction angle of soil [6].

In this research, we will design the grouting based on field data and laboratory tests so that the grouting is fulfill the requirement standard. In the implementation in earthfill dam, it is expected that strengthening of soil after grouting is not changing the materials to be concrete so that the soil can move plastically when the water flooding the dam.

\section{Methods}

\section{1 surface and Subsurface Observation}

Surface observation is figure out soil and rock identification around Kedung Uling dam. Meanwhile, core drilling is conducted to get soil samples either undisturbed sample or disturbed sample. Core drilling is followed by SPT test by 1 meter interval and undisturbed sample has interval 5 meter/ depth for mechanical soil test. Core drilling is carry out for 4 points at sliding location and 4 points at body of dam with the depth around 10 to 15 meter.

\footnotetext{
Corresponding author: najib@ft.undip.ac.id
} 


\subsection{Laboratory Tests}

Laboratory tests from undisturbed samples are set for 30 samples i.e direct Shear test and Index properties test. The results of tests will be used for slope stability analysis at the embankment wall of dam and for grouting design. The analysis has been conducted at soil mechanics laboratory (ISO 9001: 2008) at Selimut Bumi Adhi Cipta Company.

\subsection{Slope Stability Analysis}

Slide 6.0 is used for simulation of dam slope stability. In this simulation, cross section of dam model was made based on litological units from drilling discription and laboratory analytical results i.e unit weight, cohesion and internal friction angle. Before slope stability of dam is simulated, analytical of earthquake in Kedung Uling is determined based on Indonesia earthquake zonation map (fig. 1). Afterward, dam risk class (Risk factor) based on the classification as shown in Table 1 [7].

Class of Building and earthquake loading $\left(\mathrm{FR}_{\mathrm{tot}}\right)$ can be determined by using equation $1[7]$ :

$$
F R \text { tot }=F R k+F R t+F R e+F R h
$$

Kedung Uling dam will be analyzed for 100 years (T $=100$ years); Factor of safety (FS) agree with the criterion. For $\mathrm{T}=5000$ years, Factor of safety $>1$, if dinamic analysis is not fulfill. Earthquake velocity coeficient $(\mathrm{K})$ has given by equation 3 :

$$
\begin{gathered}
A d=A g \cdot V \\
K=\frac{A d}{g}
\end{gathered}
$$

Where Ad is corrected ground velocity $\left(\mathrm{cm} / \mathrm{s}^{2}\right), \mathrm{Ag}$ is Peak soil velocity (gal), V is type of soil corrected factor, $\mathrm{g}$ is gravitation velocity $\left(\mathrm{cm} / \mathrm{s}^{2}\right)$. Z (earthquake zone coeficient) can be determined by plotting research location on earthquake zonation map based on its zonation and contour. Ac can be determined from repeat period (T) where the value depends on type, class and how long the dam will be used. Ground maximum velocity (ag) is calculated from $\mathrm{Z}$ multiply by Ac. Wave velocity based on NSPT of soil. V is calculated from equation 4:

$$
T S=1.25 \sum_{i=1}^{n} \frac{4 H i}{V s i}
$$

Which FRk is capacity of dam, FRt is height of dam, FRe is evacuation need and FRh is downstream damage level. Afterward, risk class can be determined by using table 3. Earthquake loading criteria for dam design can be seen in table 2 .

\begin{tabular}{|c|c|c|c|c|c|}
\hline & \multicolumn{4}{|c|}{ weighting value in brackets } & \\
\hline Risk Factor & Ekstreme & & Tigh & Moderate & Low \\
\hline Capacity $\left(10^{8} \mathrm{~m}^{3}\right)(\mathrm{FRk})$ & $>100(6)$ & & $1,25(4)$ & $\begin{array}{c}100-0,25 \\
\text { (2) }\end{array}$ & $\begin{array}{l}<0,125 \\
\quad(0)\end{array}$ \\
\hline Height (m) (FRt) & $>45(6)$ & & $30(4)$ & $30-15(2)$ & $<15(0)$ \\
\hline $\begin{array}{l}\text { Evacuation need } \\
\text { (people number)(Fre) }\end{array}$ & $>1000(12)$ & & $-100(8)$ & $100-1(4)$ & $0(0)$ \\
\hline $\begin{array}{l}\text { Downstream damage } \\
\text { level (FRh) }\end{array}$ & $\begin{array}{l}\text { Very High } \\
\text { (12) }\end{array}$ & $\begin{array}{l}\text { High } \\
(10)\end{array}$ & $\begin{array}{c}\text { Moderately } \\
\text { high (8) }\end{array}$ & $\begin{array}{c}\text { Moderate } \\
\text { (4) }\end{array}$ & $\begin{array}{l}\text { None } \\
(0)\end{array}$ \\
\hline
\end{tabular}

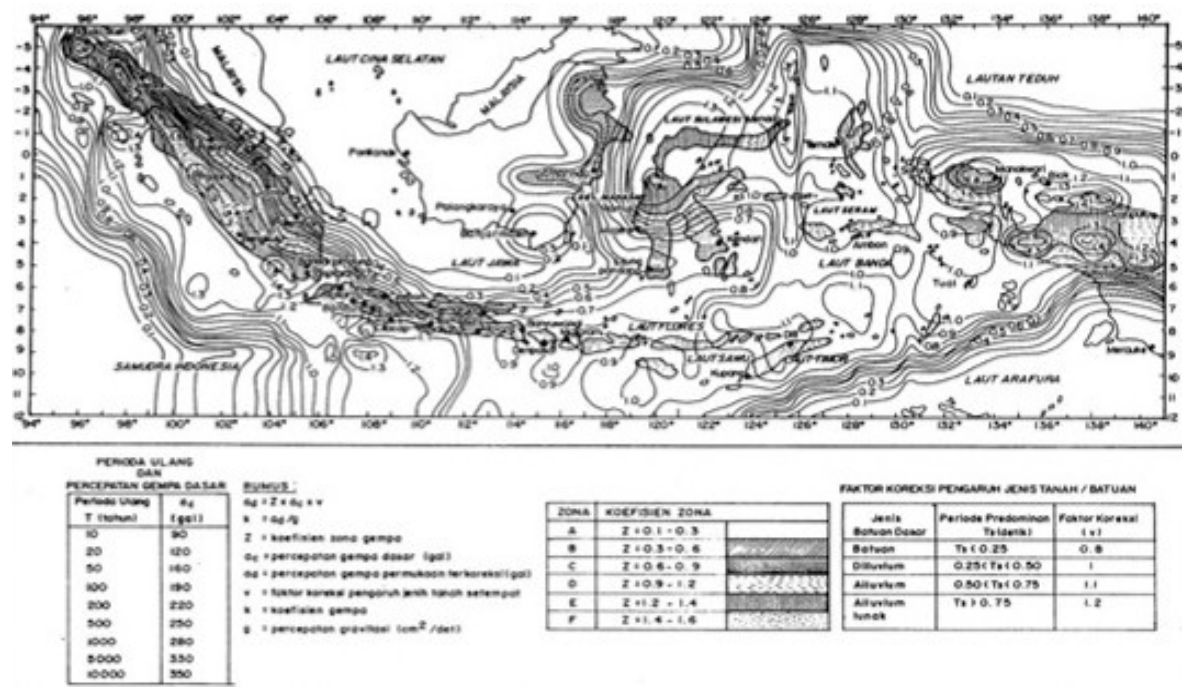

Fig.1. Indonesia earthquake zonation map [7]

Table 1. Dam Risk Classification [7] 
Table 2. Earthquake loading criteria for dam design [7].

\begin{tabular}{|c|c|c|c|c|}
\hline \multirow{2}{*}{$\begin{array}{l}\text { Risk class based on } \\
\text { time use }\end{array}$} & & \multicolumn{3}{|c|}{ Requirement allowing devastating without fail } \\
\hline & $\mathrm{T}$ (year) & $\begin{array}{c}\text { Analytical } \\
\text { method }\end{array}$ & $\begin{array}{c}\mathrm{T} \\
\text { (year) }\end{array}$ & Analytical method \\
\hline IV & $100-200$ & $\begin{array}{l}\text { Earthquake } \\
\text { coeficient }\end{array}$ & 10000 & Earthquake coeficient or dynamic* \\
\hline $\mathrm{N}=50-100$ & $\mathrm{ad} \geq 0,1 \mathrm{~g}$ & & (MDE) & \\
\hline III & $50-100$ & $\begin{array}{c}\text { Earthquake } \\
\text { coeficient }\end{array}$ & 5000 & Earthquake coeficient or dynamic* \\
\hline $\mathrm{N}=50-100$ & $\mathrm{ad} \geq 0,1 \mathrm{~g}$ & & (MDE) & \\
\hline II & $50-100$ & $\begin{array}{c}\text { Earthquake } \\
\text { coeficient }\end{array}$ & 3000 & Earthquake coeficient or dynamic * \\
\hline $\mathrm{N}=50-100$ & $\mathrm{ad} \geq 0,1 \mathrm{~g}$ & & $(\mathrm{MDE})$ & \\
\hline $\mathrm{I}$ & $50-100$ & $\begin{array}{c}\text { Earthquake } \\
\text { coeficient }\end{array}$ & 1000 & Earthquake coeficient or dynamic* \\
\hline $\mathrm{N}=50-100$ & $\mathrm{ad} \geq 0,1 \mathrm{~g}$ & & (MDE) & \\
\hline
\end{tabular}

Table 3. Risk class dam and water infrastructure [7].

\begin{tabular}{|l|l|}
\hline Total risk factor & Risk class \\
\hline$(0-6)$ & I (Low) \\
\hline$(7-18)$ & II (Moderate) \\
\hline$(19-30)$ & III(High) \\
\hline$(31-36)$ & IV(Extreme) \\
\hline
\end{tabular}

Slope stability analysis of body dam based on some condition for slope stability analysis. Ten conditions were set for Kedung Uling dam stability analysis:

1. Empty dam without earthquake loading at upstream condition.

2. Empty dam with earthquake loading at uppstream condition.

3. Empty dam without earthquake loading at downstream condition.

4. Empty dam with earthquake loading at downstream condition.

5. Maximum water level dam without earthquake loading at upstream condition.

6. Maximum water level dam with earthquake loading at upstream condition.

7. Maximum water level dam without earthquake loading at downstream condition.

8. Maximum water level dam wit earthquake loading at downstream condition.

9. Sudden water level drop without earthquake at upstream condition.

10. Sudden water level drop without earthquake at downstream condition.

Dam of stability analysis model use some parameters from soil mechanic tests such as unit weight, cohesion and internal friction angle. For earthquake analysis, it uses earthquake zone map[6].

\subsection{Grouting Design}

After slope stability of dam is being analyzed, grouting design will be simulated by using slide 6.0 .

\section{Results and Discussion}

\subsection{Surface Investigation}

Kedung Uling earthfill dam is basically underlain by Baturetno formation (Qb), which consists of grey to black clay (Surono et al, 1992). Based on surface investigation, grey to black color clay is dominant, intersected with white yellowish sand and calcareous pebble. This intersection is only found in some limited area in the dam area.

Some cracks and sliding were found at the top of the dam and embankment walls (see fig. 2). Those cracks and sliding possibly occured due to poor foundation, poor filling materials or when constructed the filling materials was not same with the procedure.

\subsection{Core Drilling}

To investigate subsurface of Kedung Uling dam, core drilling was set up in ten points and was represent dam subsurface condition. The Locations of drilling points can be seen in fig. 3. The depth of drilling was $10 \mathrm{~m}, 12$ $\mathrm{m}$ and 15 meter. Besides, SPT and permeability tests have been assembled. The results show that soil dominantly by grey to black stiff-firm clay with N-SPT 4-20.

\subsection{Laboratory Tests}

The mechanical soil tests i.e direct shear test, index properties and atterberg limit have been done. The numbers of samples are 30 samples. The results of soil tests, as shown in table 4, were used for slope stability of 
Kedung Uling dam namely unit weight, cohesion and internal friction angle.

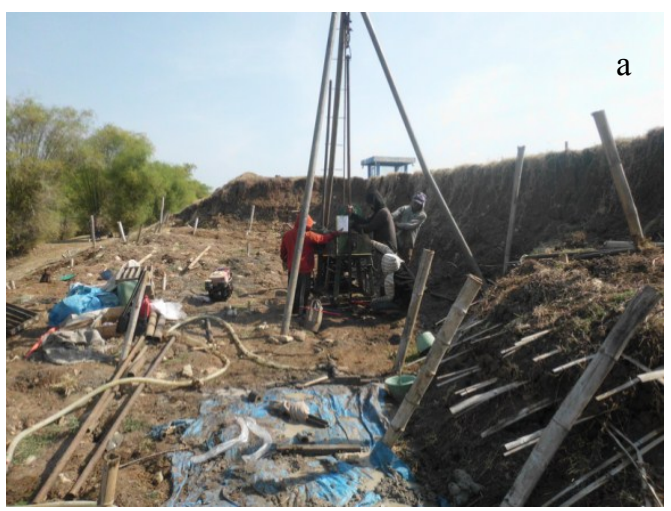

b

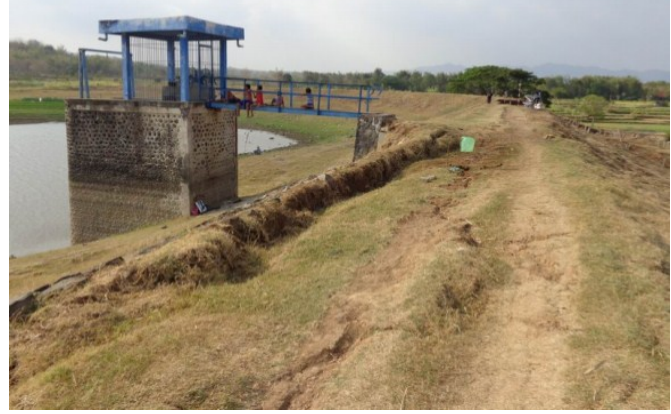

Fig. 2. Sliding (a) and cracks (b) at the top of Kedung Uling Earthfill dam.

Table 4 Mechanical soils characteristics of Dam body

\begin{tabular}{|c|c|c|c|}
\hline Material & $\begin{array}{c}\text { Unit weight } \\
\left(\mathrm{kN} / \mathrm{m}^{3}\right)\end{array}$ & $\begin{array}{c}\text { Cohesion } \\
\left(\mathrm{kN} / \mathrm{m}^{2}\right)\end{array}$ & $\begin{array}{c}\text { Internal } \\
\text { Friction } \\
\text { angle }\left({ }^{\circ}\right)\end{array}$ \\
\hline $\begin{array}{c}\text { Filling impervious } \\
\text { clay material }\end{array}$ & 18.3 & 15.7 & 18.3 \\
\hline $\begin{array}{c}\text { Filling old } \\
\text { impervious black } \\
\text { clay material }\end{array}$ & 22.2 & 15.2 & 11.92 \\
\hline $\begin{array}{c}\text { Filling old } \\
\text { impervious grey } \\
\text { clay material }\end{array}$ & 20.17 & 14.42 & 14.97 \\
\hline Bedrock & 20 & 7.1 & 30.59 \\
\hline
\end{tabular}

\subsection{Slope Stability Analysis of Dam}

Based on Indonesia earthquake zonation map [7] (Fig. 2) and equation (1-4), Kedung Uling Earthfill dam can be categorized as shown on table 5 .

Table 5 Determination of building class and earthquake loading.

\begin{tabular}{|l|l|l|}
\hline Dam condition & Information & Factor \\
\hline Dam capacity & $366.646 \mathrm{~m}^{3}$ & FRk $=2$ \\
\hline Dam Height & $9 \mathrm{~m}$ & Frt $=0$ \\
\hline Evacuation need & $0-200$ people & Fre $=4$ \\
\hline Upstream danger level & Moderately high & RFh $=8$ \\
\hline & & Frtotal $=14$ \\
\hline
\end{tabular}

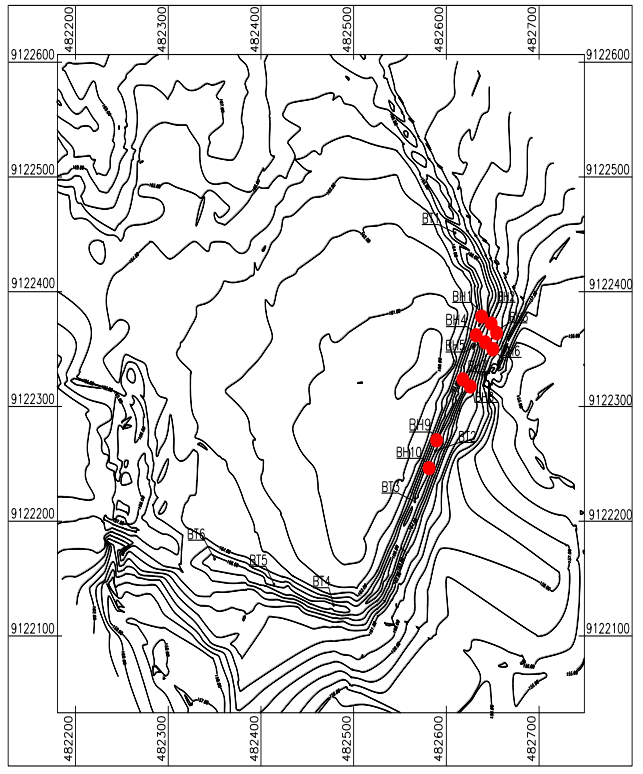

Fig.3 Core drilling location (dots are core drilling location).

Based on table 5, the total risk factor, Kedung Uling dam is categorized in class II (moderate). Table 6 shows the results of calculation of earthquake coeficient based on equation 1-4.

Table 6 Earthquake coeficient calculation

\begin{tabular}{|l|l|}
\hline Parameter & Information \\
\hline Top soil velocity (Ac) & $\begin{array}{l}\mathrm{T}=100 \text { year } \\
\mathrm{Ac}=190 \mathrm{gal}\end{array}$ \\
\hline Earthquake zone coeficient (z) & $\mathrm{z}=0.2$ (average) \\
\hline Ground maximum velocity (ag) & ag $=38 \mathrm{~g}$ \\
\hline Wave disperse velocity (Vs) & $\begin{array}{l}\text { NsPT }=12 \\
\text { Vs }=337.5 \mathrm{~m} / \mathrm{s}\end{array}$ \\
\hline Soil type correction (Ts) & $\begin{array}{l}\text { Ts }=0.444 \text { Detik } \\
\text { Foundation :Dilluvium } \\
\text { V = } 1 \text { with } 0.25<\mathrm{Ts} \\
<0.50\end{array}$ \\
\hline $\begin{array}{l}\text { earthquake velocity plan(ad) } \\
\text { coeficient(K) }\end{array}$ & $\mathrm{Ad}=38$ gal \\
\hline
\end{tabular}

Based on the 10 conditions of Kedung Uling dam, there are two conditions of Kedung Uling dam which are not fulfill SNI standard (table 7).

The condition of dam with the maximum water level with and without earthquake load are not satisfy value of safety factor of SNI standard (table 7). This means Kedunguling has sliding potential. In fact, kedung uling dam has settlement so that dam body falled down (see fig. 2). Cracks were found in several parts top of dam where the materials are black clay with high plasticity and low permeability.

\subsection{Analytical slope stability after grouting in sliding location}


To understand value of factor of safety, it has been conducted simulation of slope stability after grouting and compared cohesion value with its factor of safety(fig. 4). Cohesian should be at least $\geq 17 \mathrm{kN} / \mathrm{m}^{2}$ to get minimum SNI standard requirement of the body of dam. The model can be seen in fig. 5 .

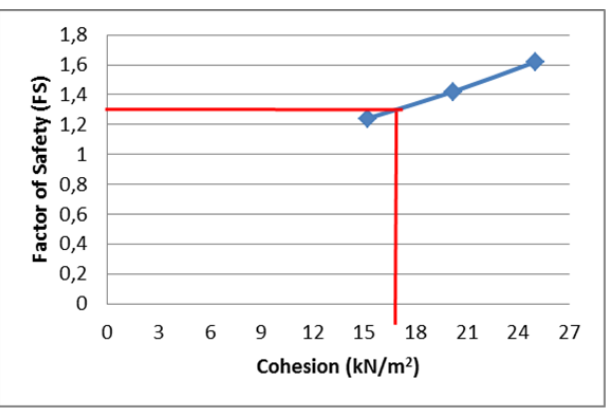

Fig.4. Comparison between FS and Cohesion .

\subsection{Grouting Simulation}

Grouting was simulated at three locations i.e upstream, top of dam and downstream (see figure 6). Slope stability has been simulated with three different cohesion (Fig.7-9). Slope stability also has been simulated with earthquake loading (Fig.10). From the results, factor of safety value is parallel with cohesion value. Comparison between cohesion after grouting and factor of safety is shown in fig. 10. Cohesion after grouting should be $\geq 24 \mathrm{kN} / \mathrm{m}^{2}$ for getting factor of safety to reach SNI standard namely $\geq 1,3$ (Fig. 10).

Table 7 Slope stability analytical results comparing with SNI Standard

\begin{tabular}{|c|c|c|c|c|}
\hline No. & Dam condition & FK & $\begin{array}{c}\text { Requirement } \\
\text { of safety } \\
\text { value (SNI) }\end{array}$ & Information \\
\hline 1 & $\begin{array}{l}\text { Empty dam without earthquake } \\
\text { loading at upstream }\end{array}$ & 1.766 & 1.4 & satisfy \\
\hline 2 & $\begin{array}{l}\text { Empty dam with earthquake } \\
\text { loading at upstream }\end{array}$ & 1.570 & 1.2 & satisfy \\
\hline 3 & $\begin{array}{l}\text { Empty dam without earthquake } \\
\text { loading at downstream }\end{array}$ & 1.512 & 1.4 & satisfy \\
\hline 4 & $\begin{array}{l}\text { Empty dam without earthquake } \\
\text { loading at upstream }\end{array}$ & 1.367 & 1.2 & satisfy \\
\hline 5 & $\begin{array}{l}\text { Maximum water level dam } \\
\text { without earthquake loading at } \\
\text { upstream }\end{array}$ & 2.538 & 1.3 & satisfy \\
\hline 6 & $\begin{array}{l}\text { Maximum water level dam with } \\
\text { earthquake loading at upstream }\end{array}$ & 2.041 & 1.1 & satisfy \\
\hline 7 & $\begin{array}{l}\text { Maximum water level dam } \\
\text { without earthquake loading at } \\
\text { downstream }\end{array}$ & 1.206 & 1.3 & unsatisfy \\
\hline 8 & $\begin{array}{l}\text { Maximum water level dam with } \\
\text { earthquake loading at } \\
\text { downstream }\end{array}$ & 1.081 & 1.1 & unsatisfy \\
\hline 9 & $\begin{array}{l}\text { Sudden water level drop without } \\
\text { earthquake at upstream }\end{array}$ & 1.300 & 1.2 & satisfy \\
\hline 10 & $\begin{array}{l}\text { Sudden water level drop without } \\
\text { earthquake at downstream }\end{array}$ & 1.402 & 1.2 & satisfy \\
\hline
\end{tabular}

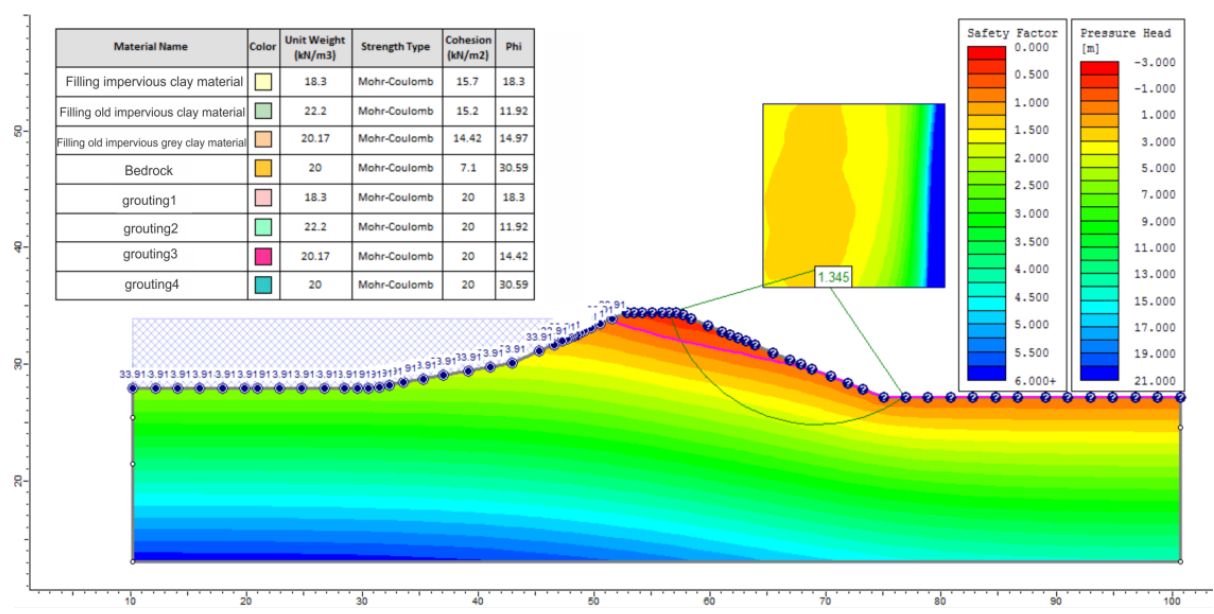

Fig. 5 Grouting simulation result of embankment which is encounter sliding. Cohesian value is $17 \mathrm{kN} / \mathrm{m}^{2}$. 


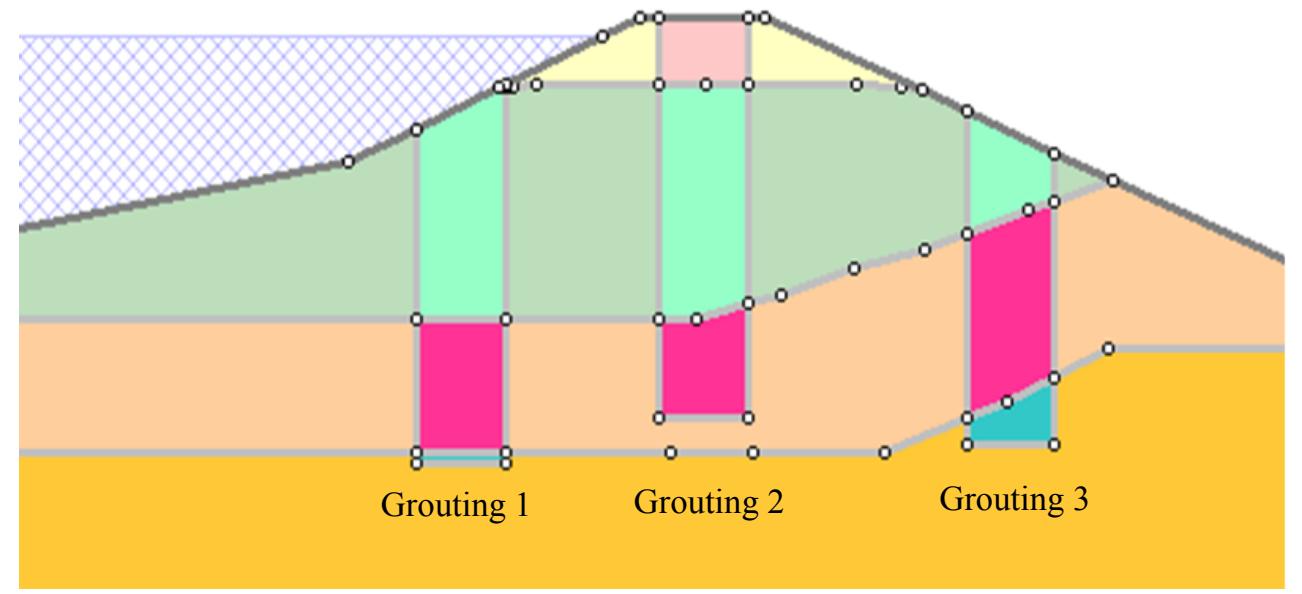

Fig.6 Grouting location points.

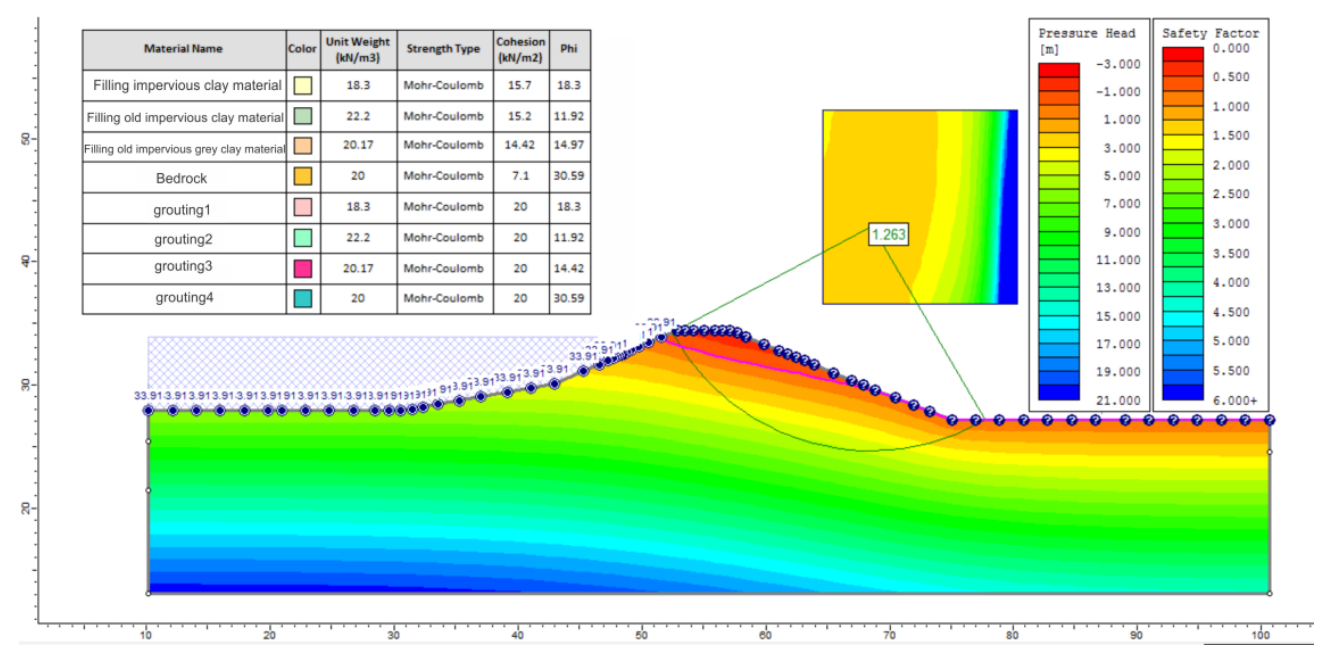

Fig. 7 Slope stability analysis after grouting is being assembled. Cohesion is $20 \mathrm{kN} / \mathrm{m}^{2}$ after grouting.

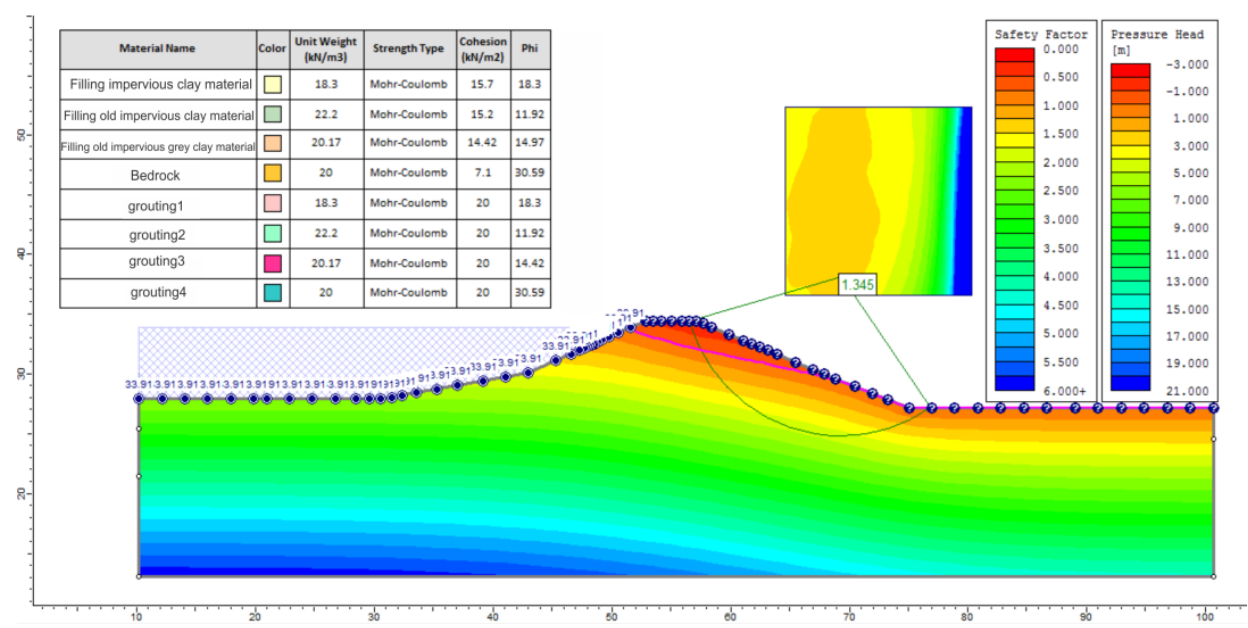

Fig. 8 Slope stability analysis after grouting is being assembled. Cohesion is $30 \mathrm{kN} / \mathrm{m}^{2}$ after grouting. 


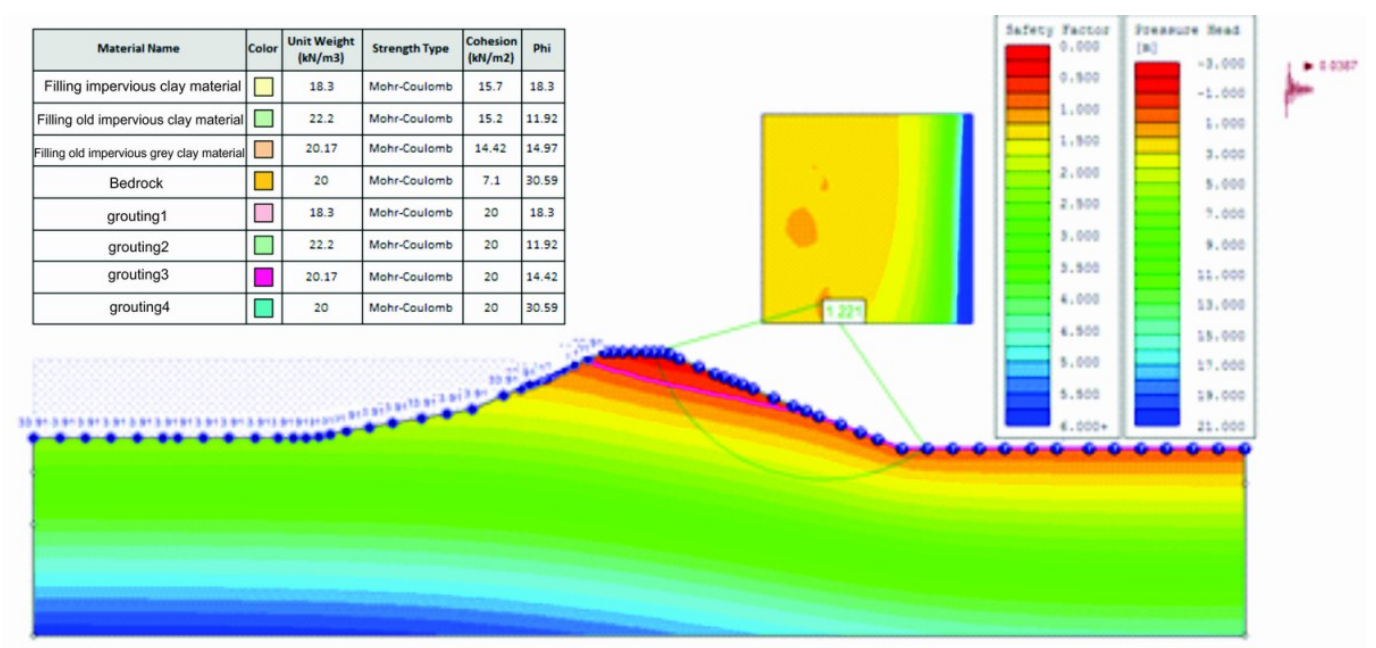

Fig. 9 Slope stability analysis after grouting is being assembled. Cohesion value is $20 \mathrm{kN} / \mathrm{m}^{2}$ with earthquake loading.

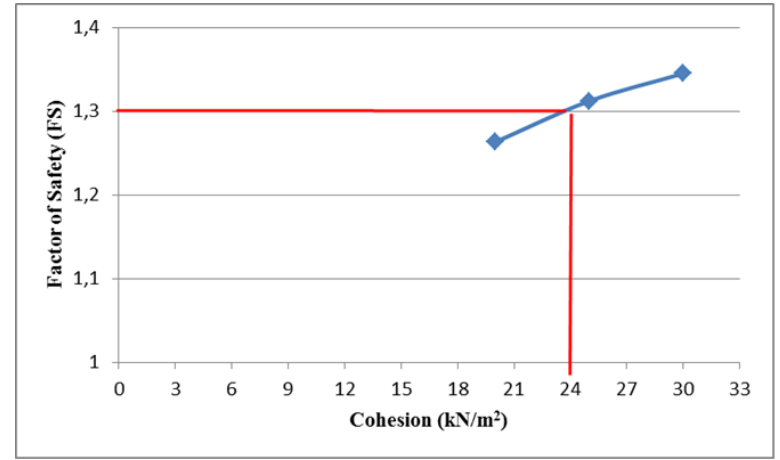

Fig.10. Safety Factor versus Cohesion.

\section{Conclussions}

We conclude that Factor of safety (FS) of dam in condition Unstable dam maximum water level without and with earthquake downstream part is not satisfy with FS of SNI standard i.e 1.206 and 1.081, respectively. After grouting with cohesian value $\geq 24 \mathrm{kN} / \mathrm{m}^{2}$, FS has fulfill SNI standard $(\geq 1,3)$.

We thankfully appreciate for any supports from PT. Selimut Bumi Adhi Cipta and BWWS Solo, helped us in data and discussion. Research has supported by PNBP DIPA Diponegoro University No: SP DIPA-042.01.2.400898/2016, 7 Desember 2015, Fiscal year 2016.

\section{References}

1. R. Fell, P., MacGregor, D., Stapledon, G., Bell. Geotechnical Engineering of Dams (A.A. Balkema Publishers, Singapore, 2005)

2. J.,Warner, Practical Handbook of Grouting Soil, Rock and Structures (John Wiley \& Sons, Mariposa, California, 2004)
3. P.G., Nicholson, Soil Improvement and Ground Modification Methods (Elsevier Inc., New York, 2015).

4. S.,Turkmen, Eng. Geo. 68,159-169 (2003).

5. C.P., Yang, Eng. Geo.75, 1 -14 (2004).

6. M.Y, Fattah, M.M, Al-Ani, M.T.A., Al-Lamy, Soils and Foundations J. 54,3, 396-404 (2014).

7. Keputusan Menteri Permukiman dan Prasarana Wilayah Nomor : 360/KPTS/M/ 2004 tentang Analisis stabilitas bendungan tipe urugan akibat beban gempa, Pd T-14-2004-A (2004). 